\title{
Land-use and climate change effects in forest compositional trajectories in a dry Central-Alpine valley
}

\author{
Urs GimMI*, Thomas Wohlgemuth, Andreas Rigling, Christian W. HofFMANN, Matthias BÜRGI
}

Swiss Federal Research Institute WSL, Zürcherstrasse 111, 8903 Birmensdorf, Switzerland

(Received 6 November 2009; accepted 18 February 2010)

Keywords:

historical ecology /

anthropogenic disturbance /

land-use history /

woodland pasture /

forest litter collecting

\begin{abstract}
- Increased mortality of Scots pine (Pinus sylvestris L.) and spreading of deciduous trees are observed in the Swiss Rhone valley. Previous research identified climate change effects as main drivers of this trend. On the local scale, we hypothesize that legacies from past anthropogenic disturbances are superimposed on climate effects.

- We reconstructed land-use history and quantified changes in tree species composition from 1930 to 1994 on 9468 ha of forested land. The aim was to analyze the contribution of anthropogenic disturbances to the observed changes and to disentangle human impact from climate change effects.

- At altitudes below $1200 \mathrm{~m}$ a.s.l. we found a shift from pine $(-11.4 \%)$ to deciduous trees $(+11 \%)$ with significantly lower increase of deciduous trees in stands formerly used for grazing and/or litter collecting. Conversely, pine decrease was not correlated with former anthropogenic disturbances. We interpret pine mortality as an effect of increased drought stress due to climate change while spread of deciduous trees is driven by land-use change. Grazing and litter collecting hindered deciduous tree regeneration and it was not until their abandonment a few decades ago that forest composition started to change. At higher elevations the shift from Norway spruce (Picea abies; $-8.5 \%$ ) to European larch (Larix decidua $;+8.2 \%$ ) corresponds to silvicultural management schemes, aimed at promoting larch recruitment.

- Our study illustrates the importance of disentangling climate from land-use change effects for understanding shifts in forest composition. The findings are relevant for other regions in the European Alps where forests undergo comparable environmental changes.
\end{abstract}

\section{INTRODUCTION}

Despite the increase of direct or indirect effects of climate change on forest growth (Leuzinger et al. 2005; Spiecker et al., 1999) and on forest dynamics (Fuhrer et al., 2006), in many forest stands both composition and structure is more distinctly reflected by past anthropogenic disturbances than by effects of climate change (Foster et al., 2003; Hansen et al., 2001; Wohlgemuth et al., 2002). This particularly holds true for forests in Central Europe featuring a long tradition of human activities (Birks et al. 1988; Dambrine et al. 2007; Kirby and Watkins 1996). Land-use history is therefore recognized as a key factor to understand present forest composition and trajectories of change at different spatial and temporal scales (Axelsson and Östlund, 2001; Foster, 2002). Forest response to past land-use is sensitive to the type, duration and intensity of past practises (Prévosto et al., 2004; Wulf, 2004) as well as the time since land-use abandonment (Chauchard et al., 2007; Graae et al., 2003).

In European mountain forests characterized by short growing seasons, the effects from past anthropogenic disturbances tend to last longer than in more productive lowland forests

\footnotetext{
*Corresponding author: urs.gimmi@wsl.ch
}

(Garbarino et al., 2009; Motta and Garbarino, 2003). In addition, the effects of climate change are considered to be more pronounced in contrast to lowland ecosystems. Disentangling the effects of climate from land-use change is needed to better understand current forest composition and to evaluate future trajectories of forest dynamics. Whereas climate change slowly impacts nature at all scales continuously, changes of land-use affect forests quicker though at limited scales (Albert et al., 2008; Motta et al., 2006).

We hypothesize interactions between climate and landuse changes to explain recently detected changes in tree species composition in forests of the upper Swiss Rhone valley (Valais). Here, increased mortality of Scots pine ( $P i$ nus sylvestris L.) and a significant shift from the sub-boreal pine to the sub-Mediterranean downy oak (Quercus pubescens Willd.) have been observed in the last decades (Rigling and Cherubini, 1999; Rigling et al., 2004). Fluorine emission was identified as the main cause of needle necrosis observed locally nearby aluminum smelters since the 1920s (Flühler et al., 1981). After the installation of filter systems in the early 1980 s the local necrosis symptoms disappeared. However, mortality rates remained high or even increased in areas where fluorine loads has never been high and there is 
no evidence that other pollutants may be responsible for this effect (Rigling and Cherubini, 1999). Previous studies identified direct and indirect climate change effects namely increased drought stress (Bigler et al., 2006; Dobbertin et al., 2005; Rebetez and Dobbertin, 2004) and altered natural disturbance regimes (Gimmi et al., 2004; Schönfeld et al., 2004; Wermelinger et al., 2008; Zumbrunnen et al., 2009) as the main drivers of the shift in tree species composition. Because local-scale changes are not yet sufficiently understood, this study evaluates the role of historic anthropogenic disturbance regimes. As the most important non-timber forest uses, forest litter collecting and wood pasture by domestic goats have been identified in the region (Gimmi and Bürgi, 2007). These traditional forest uses were often more important than timber harvesting, especially in forests with low productivity such as the Scots pine stands (Gimmi et al., 2008). Forest litter was used as a substitute for straw to bind the livestock dung in the stable. Wood pasture in this Alpine region was mainly done by goats. Goats stayed in the villages to provide the local people with milk during summer when the cattle were driven to the mountain pastures in the subalpine and alpine zones. Traditionally, the animals grazed in the forests surrounding the villages. Litter collecting and wood pasture were practised in varying intensity on an essential portion of the forested area until the 1950's (Bürgi and Gimmi, 2007; Gimmi et al., 2008). Only recently, the magnitude of grazing impact in forests has been revealed by the surprising abundant emergence of the rare, presumably goat-dispersed plant species Blitum virgatum, after a large forest fire (Moser et al., 2006).

Similar to the Valais, such legacies derived from former grazing activities have been detected for forests throughout the whole European Alps (Chauchard et al., 2007; Curt et al. 2003, Motta et al. 2006). To study the combined effects of changes in land-use and climate on forest ecosystems, we reconstructed compositional changes on more than 300 parcels of forested land with known land-use history. The dataset serves to (i) identify the patterns and trajectories of change in forest composition in the upper Swiss Rhone valley since 1930 and (ii) to characterise the impact of historic anthropogenic disturbance regimes on regional dynamics in tree species composition.

\section{MATERIALS AND METHODS}

\subsection{Study area}

The canton (i.e., a government district) of Valais is situated in the south-western part of Switzerland bordering Haute-Savoie in France to the West, and the Val d'Aosta in Italy to the south (Fig. 1). The Valais contains the main part of the catchments area of the upper Rhone to its mouth into the Lake of Geneva. The mountains surrounding the valley (highest top $4634 \mathrm{~m}$ a.s.1.) shield the inner part of the valley from the moist oceanic air masses transported by western and southern winds. This inner-Alpine situation causes a "rain shadow", making the central Valais a very dry region (annual precipitation at Sion is $598 \mathrm{~mm}$; Rebetez and Dobbertin, 2004). mean annual precipitation is increasing with altitude (Moser et al., in review). The area under investigation in this study covers 9468 ha of public forests
Table I. Conversion key to transform tree species mentioned in Werlen (1994) into percentage of tree species.

\begin{tabular}{cl}
\hline Number of tree species & Percentage \\
\hline 1 & 100 \\
2 & 70,30 \\
3 & $50,30,20$ \\
4 & $40,30,20,10$ \\
\hline
\end{tabular}

in 22 municipalities in the upper central Valais (Fig. 1). The forests range in elevation from $540 \mathrm{~m}$ a.s.l. in the valley bottom to the upper tree line at about $2400 \mathrm{~m}$ a.s.l. These forests were chosen due to the excellent historical source availability, especially forest management plans which are a valuable source for reconstructing historic forest conditions and forest uses (Bürgi, 1999; Gimmi and Bürgi, 2007; Gimmi et al., 2009).

\subsection{Dependent variables: change in tree species composition}

Historical tree species composition derives from forest management plans of 22 municipalities in the upper central Valais established between the mid 1920s and the late 1930s. In the following, the reconstructed forest composition for this time is referred to as "tree species composition 1930". These forest management plans contain standing timber inventories by full callipering $(100 \%$ cruise with lower limit of diameter at breast height $(\mathrm{DBH})=12 \mathrm{~cm}$ ) and maps for totally 316 forest compartments, all larger than 1 ha; smaller compartments have been excluded from the beginning. The results of the inventories are reported as percentage of stem number per tree species. Forest management plans distinguish five different conifer species: Scots pine (Pinus sylvestris L.), spruce (Picea abies (L.) H. Karst.), larch (Larix decidua Mill.), fir (Abies alba Mill.) and Swiss stone pine (Pinus cembra L.). As the differentiation of deciduous trees is often missing in the management plans all deciduous trees had to be subsumed in one single class. The main deciduous tree species in the region are downy oak (Quercus pubescens Willd.), white birch (Betula pendula Roth), common whitebeam (Sorbus aria (L.) Crantz) with cherry (Prunus avium L.), European ash (Fraxinus excelsior L.) and European aspen (Populus tremula L.) mixed in. Modern tree species composition derives from the vegetation map of Werlen (1994) and in the following referred to as "tree species composition 1994". This map provides information about the occurrence of tree species given in a ranking according to their relative dominance. The sequel of species listed reflects a declining occurrence (Werlen, 1994). This information was converted into percentage per tree species using the conversion key shown in Table I. The consequence of this procedure on the reliability of the results will be discussed.

The spatial resolution of the modern vegetation map is higher than those of the forest compartments in the historic forest management plans. To make both datasets comparable, modern tree species composition was aggregated into the boundaries of the old forest compartments by spatial weighting (in average one compartment contains eight polygons reflecting modern species compostion). Changes in tree species composition was expressed by absolute change in species proportion. Finally, we removed all compartments that have been affected by a large forest fire during the last $100 \mathrm{y}$ from the analysis ( $n=6)$ according to information from a regional forest fire database (Gimmi et al., 2004; Zumbrunnen et al., 2009). It is important to keep 


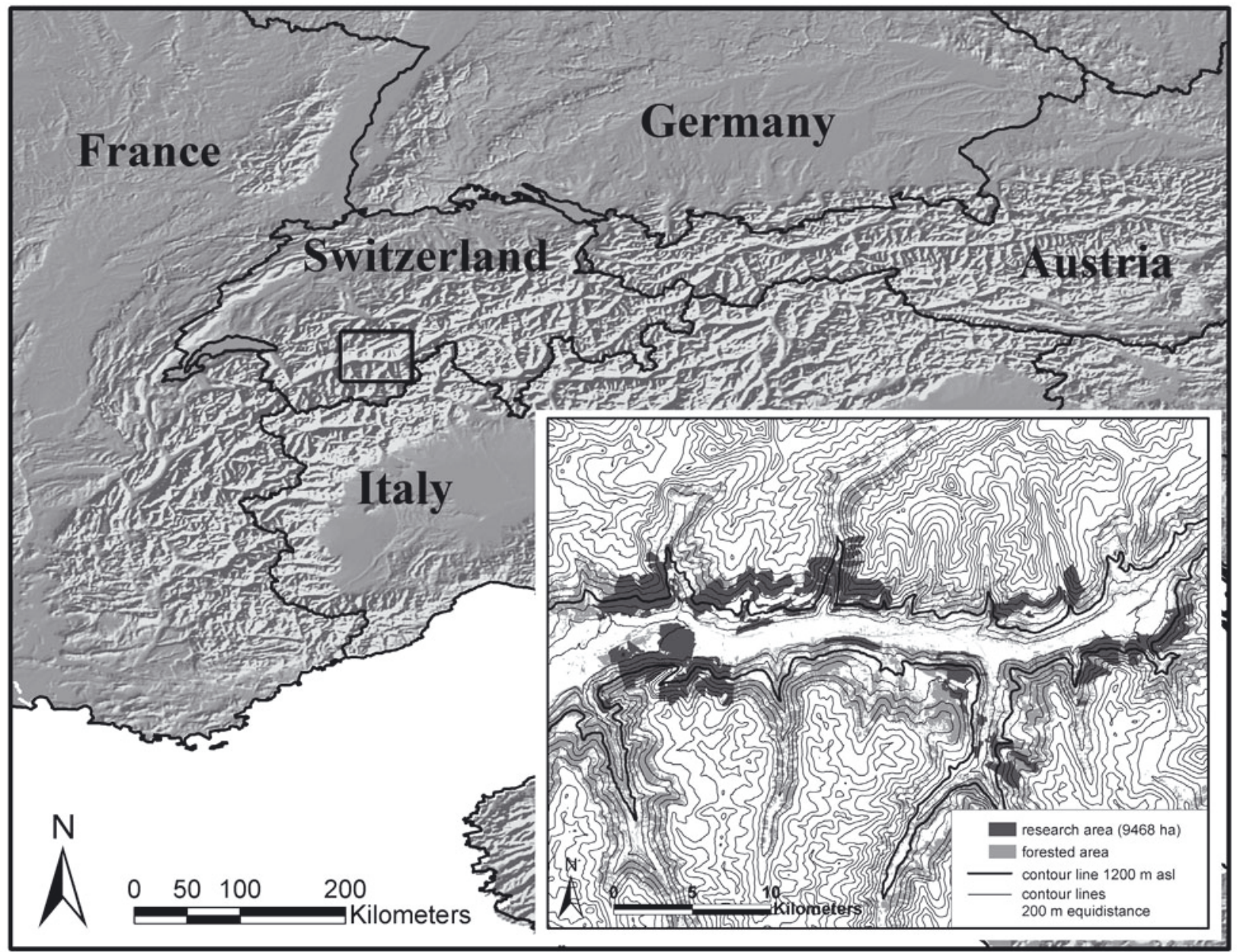

Figure 1. Location of the upper Swiss Rhone valley within the Alpine arc and location of the research area.

in mind that only vegetation changes within forests are analyzed, e.g., vegetation changes due to agricultural land-use abandonment are not considered.

\subsection{Explanatory variables: historical and site parameters}

In addition to the tree species composition dataset, the historic forest management plans provided information on silvicultural management and traditional non-timber forest uses such as wood pasture and forest litter collecting (Gimmi and Bürgi, 2007). Wood pasture in the region was almost exclusively done by goats and sheep. Forest litter was used as substitute for straw to bind the livestocks manure in the barn during wintertime. These two forest uses were practised at all elevations from the valley bottom to the upper treeline with lowproductive pine forests and other forests with minor importance for timber production particularly affected (Gimmi et al., 2008). Practice of wood pasture and litter collecting were recorded at the level of forest compartments. Based on this spatiotemporal information and on socioeconomic variables (e.g., livestock numbers and availability of substitute products) a quantitative estimation of the amount of biomass extracted due to wood pasture and forest litter collecting was performed (for methodological details see Gimmi et al., 2008). The intensity of the practices peaked during the Second World War. This unique quantitative information allowed the inclusion of different levels of intensity of wood pasture and litter collecting into the analysis. For this study we used two classes of intensity: high (above median intensity) and low (below median intensity). The median value amount to $0.06 \mathrm{~kg} \mathrm{~m}^{-2} \mathrm{y}^{-1}$ consumed dry biomass for wood pasture and to $0.23 \mathrm{~kg} \mathrm{~m}^{-2} \mathrm{y}^{-1}$ removed dry biomass for litter collecting respectively (Gimmi et al., 2008). High intensity for the combined practice of wood pasture and litter collecting means that both values exceed the respective median values.

Further, we gained topographical information from a digital elevation model (DHM-25; (c) Bundesamt für Landestopographie) by calculating mean altitude, mean slope, northness and eastness for each forest compartment. Finally, a rough geological classification into the substrates calcareaous, intermediate and crystalline was derived from the geotechnical map of Switzerland (De Quervain et al., 1963-1967; BFS GEOSTAT/BUWAL, 2001).

\subsection{Data processing}

Redundancy analysis (RDA) - also called reduced-rank regression - was used to evaluate the relative impact of different land-use types, 


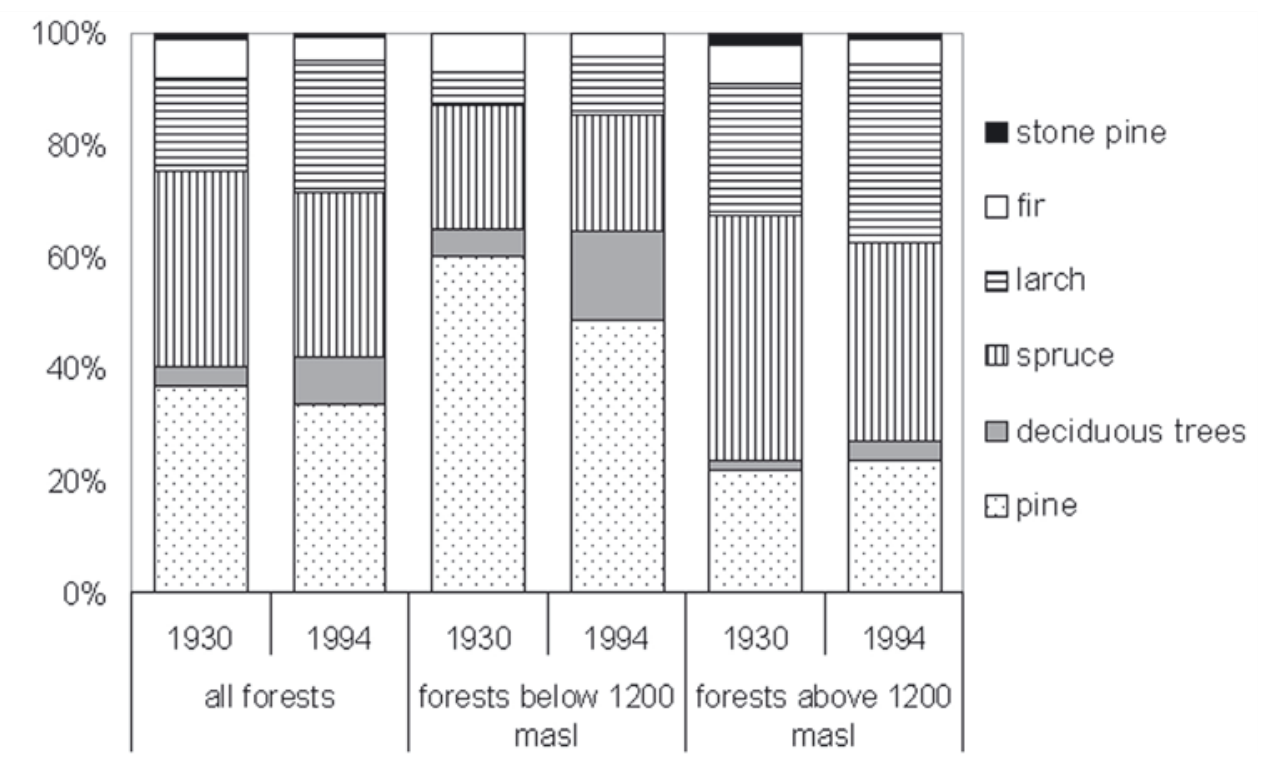

Figure 2. Tree species composition in 1930 and in 1994 below and above $1200 \mathrm{~m}$ a.s.1.

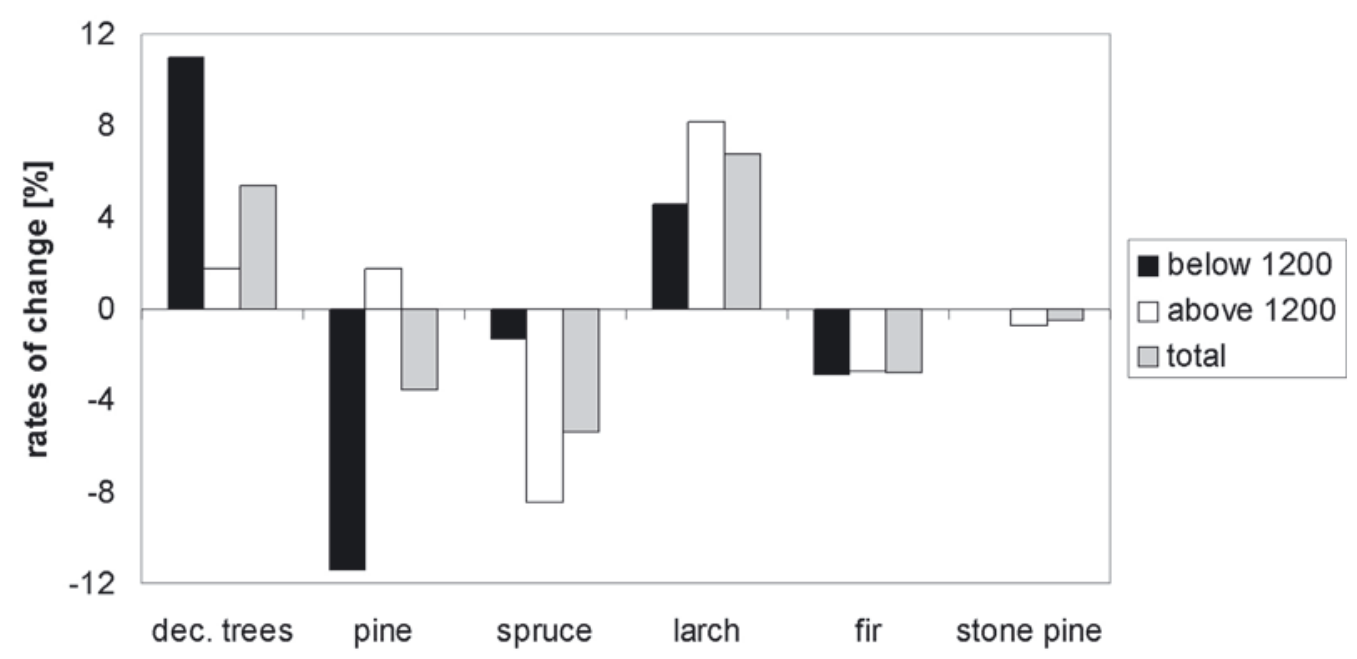

Figure 3. Rates of change in tree species composition between 1930 and 1994 below and above 1200 m a.s.1.

topography and geology on changes in tree species composition between 1930 and 1994. RDA is a multivariate statistical method frequently used in community ecology to analyse relationships between species and environmental variables (Leps and Smilauer, 2003). In this context redundancy expresses how much of the variance in one set of variables can be explained by the other. RDA served to examine how tree species composition in two time steps is related to a set of environmental variables. RDA was calculated separately for compartments below $1200 \mathrm{~m}$ a.s.l. $(n=123)$ and for compartments above $1200 \mathrm{~m}$ a.s.l. $(n=187)$. The rational of splitting the dataset at $1200 \mathrm{~m}$ a.s.l. is because $1200 \mathrm{~m}$ represents the upper limit of downy oak occurring as trees within stands. In a second step, we assessed the impact of different anthropogenic disturbance regimes, i.e., forest litter collecting, wood pasture and combination of both practices with two levels of intensity, on changes in tree species composition in the pine forest belt (forests below $1200 \mathrm{~m}$ a.s.l. and pine proportion $\geq 20 \%$ ). For this purpose we compared mean changes in the proportion of pine and deciduous trees from 1930 to 1994 between stands that have not been affected by forest litter collecting and wood pasture and stands under various anthropogenic disturbance regimes. For the analysis we applied the non-parametric Wilcoxon signed-rank test. Analyses were performed in CANOCO version 4.5 (Microcomputer Power, Ithaca, NY) for the RDA and R Statistics version 2.8.0 for the Wilcoxon test.

\section{RESULTS}

Scots pine at lower altitudes and spruce in combination with larch at higher altitudes are the dominant tree species in the region (Fig. 2). We detected two main shifts in tree species composition from 1930 to 1994 (Fig. 3). A decrease 

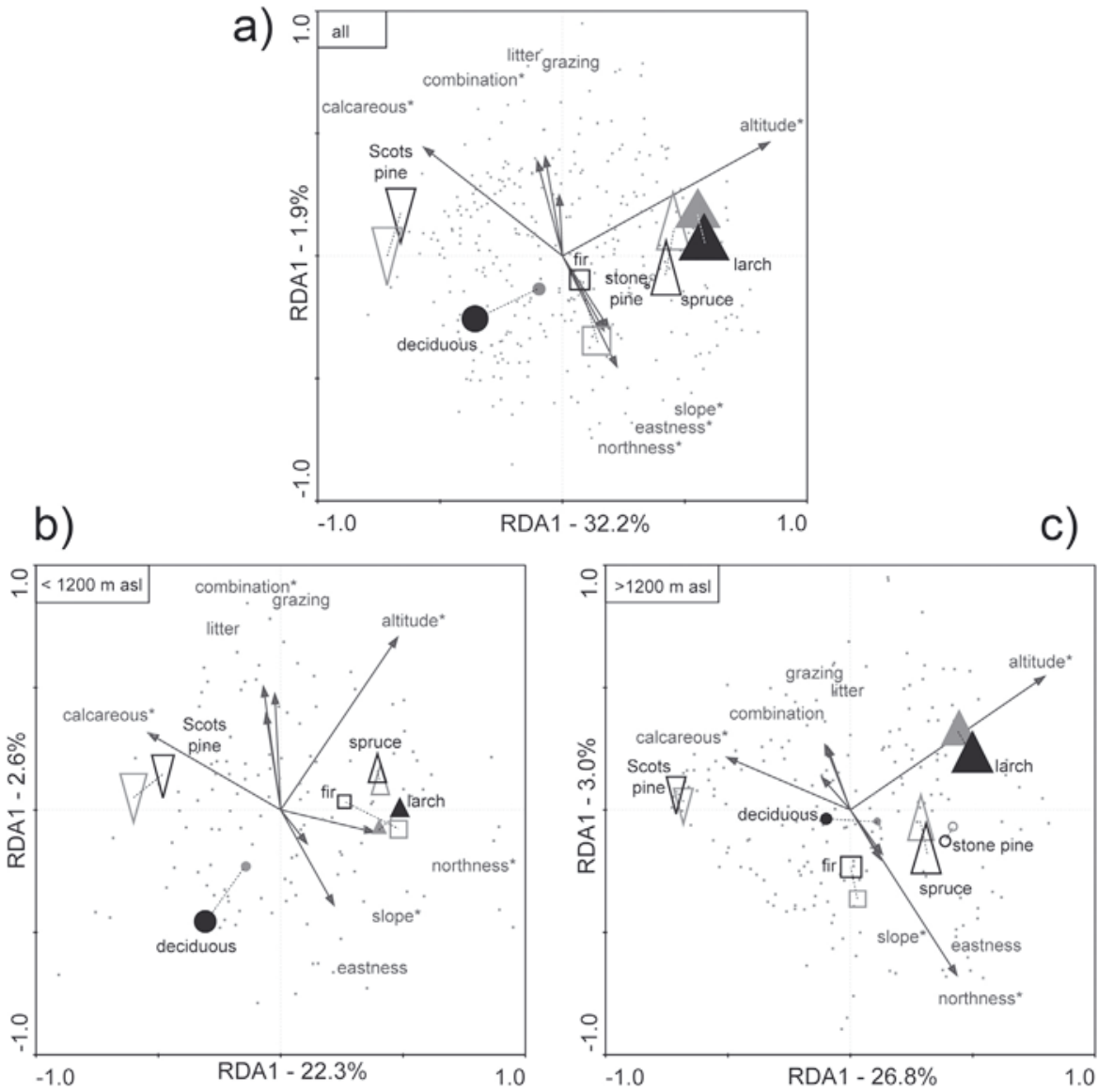

Figure 4. Ordinations of redundancy analyses of forest compartments in the central Valais: (a) all 310 compartments (total variance explained: 35\%; species-environment correlations axes 1 and 2: 0.76 and 0.46); (b) 123 compartments below $1200 \mathrm{~m}$ a.s.1. (28\%; 0.65, 0.47); and (c) 187 compartments above 1200 m a.s.l. (33\%; 0.74, 0.41). Grey and black symbols indicate years 1930 and 1994, respectively; symbol heights correspond to the square root of cover sums; environmental variables with asterisks are significant.

of Scots pine $(-11.4 \%)$ that was almost compensated for by an increase of deciduous trees $(+11 \%)$ was found in forests below $1200 \mathrm{~m}$, while at higher elevations a shift from spruce $(-8.5 \%)$ to larch $(+8.2 \%)$ was the most important pattern of compositional change. In comparison, other tree species showed only marginal changes. Fir decreased uniformly at all elevations with a moderate amount $(-2.7 \%)$, and stone pine was sparsely present near the upper tree line at both time periods.

Redundancy analysis (RDA) for all 310 compartment shows that tree species composition is best explained by altitude, northness and the content of calcareous substrate in the soil (Fig. 4a and Tab. II). Scots pine and deciduous trees dominate at lower elevations on calcareous substrate with pine occurring mainly on the southern exposed side of the valley. Larch and spruce predominately occur at higher altitudes where calcareous substrate is covered by thick humus layers or crystalline bedrocks are prevailing. In forest below $1200 \mathrm{~m}$ pine is best represented on calcareous substrates on southern exposed slopes and deciduous trees predominately occur in stands at lowest elevations (Fig. 4b). Results indicate that the increase of deciduous trees is most distinct in low elevation forests (under drier conditions) and in stands formerly not affected by grazing and litter collecting. In contrast, the cover of pine largely decreased independently from land-use type and the species seems to be more persistent at higher elevation where climate is less dry. Tree species distribution in forest above $1200 \mathrm{~m}$ follows an altitudinal gradient with larch dominating at highest elevation, spruce at mid-elevation and pine restricted to stands at lowest elevation (Fig. 4c). Spruce persisted best at northerly exposed slopes. Unlike the forests below $1200 \mathrm{~m}$, traditional forest uses seem not to be relevant for explaining changes in tree species composition at higher altitudes.

We found different trajectories of compositional change for pine stands under different anthropogenic disturbance regimes (Tab. III). Litter collecting and the combined practise with wood pasture corresponded to a significantly lower increase of deciduous trees. The effect is more pronounced when these practices have been implemented in high intensity. In stands heavily affected by both practices the increase of deciduous trees was virtually absent $(+1.2 \%)$. In contrast, changes in pine proportions were not strongly related to the former practice 
Table II. Statistical significance of environmental variables used in Redundancy Analyses: series of best fitting variables according to stepwise manual forward selection with increasing sums of explained total variances, and explained variances of the environmental variables if used singly. $F$ - and $p$-values resulted from Monte-Carlo permutation $(n=499)$.

\begin{tabular}{|c|c|c|c|c|c|c|}
\hline & \multicolumn{3}{|c|}{ Manual forward selection } & \multicolumn{3}{|c|}{ Single variables } \\
\hline & $\%$ var. & $F$-value & $p$-value & $\%$ var. & $F$-value & $p$-value \\
\hline \multicolumn{7}{|l|}{$\overline{\text { All }}$} \\
\hline *Altitude & 0.232 & 92.80 & 0.002 & 0.230 & 92.80 & 0.002 \\
\hline *Northness & 0.288 & 24.48 & 0.002 & 0.022 & 7.00 & 0.002 \\
\hline *Calcareous & 0.326 & 16.89 & 0.002 & 0.107 & 37.05 & 0.002 \\
\hline *Eastness & 0.336 & 4.73 & 0.004 & 0.011 & 3.50 & 0.038 \\
\hline *Combination & 0.342 & 2.87 & 0.024 & 0.007 & 2.26 & 0.064 \\
\hline *Slope & 0.348 & 2.87 & 0.022 & 0.015 & 4.05 & 0.014 \\
\hline Litter & 0.352 & 1.51 & 0.188 & 0.005 & 1.60 & 0.182 \\
\hline Grazing & 0.352 & 0.24 & 0.966 & 0.002 & 0.51 & 0.666 \\
\hline \multicolumn{7}{|l|}{$<1200 \mathrm{~m}$ a.s.l. } \\
\hline *Calcareous & 0.071 & 9.23 & 0.004 & 0.071 & 9.32 & 0.004 \\
\hline *Altitude & 0.137 & 9.13 & 0.002 & 0.065 & 8.44 & 0.004 \\
\hline *Northness & 0.190 & 7.89 & 0.002 & 0.035 & 4.44 & 0.008 \\
\hline *Eastness & 0.224 & 5.08 & 0.002 & 0.017 & 2.15 & 0.092 \\
\hline *Combination & 0.243 & 2.98 & 0.028 & 0.009 & 1.15 & 0.268 \\
\hline *Slope & 0.261 & 2.80 & 0.026 & 0.005 & 0.91 & 0.412 \\
\hline Grazing & 0.267 & 0.86 & 0.444 & 0.010 & 1.16 & 0.256 \\
\hline Litter & 0.271 & 0.64 & 0.608 & 0.007 & 0.63 & 0.596 \\
\hline \multicolumn{7}{|l|}{$>1200 \mathrm{~m}$ a.s.l. } \\
\hline *Altitude & 0.176 & 39.56 & 0.002 & 0.176 & 39.56 & 0.002 \\
\hline *Northness & 0.262 & 21.30 & 0.002 & 0.066 & 13.08 & 0.002 \\
\hline *Calcareous & 0.293 & 8.18 & 0.002 & 0.075 & 15.0 & 0.002 \\
\hline *Slope & 0.304 & 2.73 & 0.024 & 0.014 & 2.65 & 0.034 \\
\hline Eastness & 0.310 & 1.61 & 0.140 & 0.006 & 1.17 & 0.266 \\
\hline Combination & 0.315 & 1.40 & 0.226 & 0.009 & 1.74 & 0.146 \\
\hline Litter & 0.323 & 2.13 & 0.068 & 0.008 & 1.40 & 0.212 \\
\hline Grazing & 0.330 & 0.51 & 0.75 & 0.006 & 1.07 & 0.350 \\
\hline
\end{tabular}

Table III. Comparison of mean changes in tree species proportion between stands not affected by anthropogenic disturbances and stands under various anthropogenic disturbance regimes (Wilcoxon test). Included in the analysis are stands below $1200 \mathrm{~m}$ a.s.l. having a pine proportion in 1930 of $\geq 20 \%$. Values are given in mean changes in percentage between 1930 and 1994 .

\begin{tabular}{|c|c|c|c|c|c|c|c|}
\hline & $\begin{array}{c}\text { No such } \\
\text { use }\end{array}$ & \multicolumn{2}{|c|}{$\begin{array}{c}\text { Intensity of } \\
\text { wood pasture }\end{array}$} & \multicolumn{2}{|c|}{$\begin{array}{c}\text { Intensity of } \\
\text { litter collecting }\end{array}$} & \multicolumn{2}{|c|}{$\begin{array}{l}\text { Intensities } \\
\text { combined }\end{array}$} \\
\hline \# Compartments & 46 & 21 & 24 & 13 & 14 & 11 & 12 \\
\hline Deciduous trees & +12.6 & +10.8 & +11.7 & $+4.5^{* *}$ & $+6.2 *$ & $+1.2 * *$ & +7.1 \\
\hline
\end{tabular}

Wilcoxon test significance: $* p<0.01$; ** $p<0.005$.

of wood pasture and forest litter collecting (Tab. III). Only the decrease of pine in stands formerly grazed at low intensity $(-21.6 \%)$ was significantly higher than in stands were no traditional forest uses were practiced.

\section{DISCUSSION}

Human activities have altered the composition and structure of pine forest ecosystems globally against a backdrop of climate change (Richardson et al., 2007). Our results demonstrate that anthropogenic disturbances have a significant im- pact on changes in tree species composition in the pine forest belt of the Swiss Rhone valley. The general trend from pine to oak can be divided into two processes: the mortality of Scots pine on the one hand and the spreading of broadleaves on the other hand. Several authors were able to relate pine mortality in the Valais directly to climate change - namely increased drought stress (Bigler et al., 2006; Rebetez and Dobbertin, 2004). Tree physiological studies show that Scots pine is more prone to drought effects than pubescent oak which is more resistant to extreme drought events (Poyatos et al., 2008; Weber et al., 2007; Zweifel et al., 2009). Rigling et al. (2006) demonstrated a doubling of mortality on the drought prone sites 
below $1200 \mathrm{~m}$ a.s.l. Above this threshold, mortality was equal to average background mortality in pine of the Swiss lowlands. Hence, our results showing a clear decline in pine proportion in lower elevation with no or only minor contribution of land-use history support the view that recent pine mortality is mainly related to climate change. However, from our data we can not exclude alternative factors being relevant for pine decline in some stands. For example, effects from former fluorine damage may still be displayed in our records although presumably only for a few stands located nearby the previous emission sources. Further, stand descriptions in forest management plans suggest that a number of stands were established after clear-cuts in the first half of the 19th century and therefore now show an even age distribution. For these stands, agerelated decline may recently have become a relevant factor. These local drivers may amplify the regional climate-related trend of pine decline at lower elevations.

The spreading of broadleaves in contrast was demonstrated as mainly driven by past land-use practices: repeated wood pasture and litter raking - particularly if intensively exercised - apparently created environmental conditions which hindered regeneration of deciduous trees. As the practises were not performed homogeneously over the entire compartment (Gimmi et al., 2008) the local intensity and consequently the ecological effect of wood pasture and litter collecting could have been even stronger. In a similar way we assume that the inclusion of the exact timing since abandonment would have produced an even clearer picture of land-use change effects on forest composition in the region.

Experimental studies identified nutrient depletion and reduced acid neutralizing capacity as the most important effects of biomass removal in forest soils (Glatzel, 1990; 1991). Depth and quality of the litter layer is an important factor to explain germination success (Dzwonko, 2001). A litter removalexperiment in mixed oak-pine woodlands in Poland empirically proved how continuous litter removal caused differences in vegetation patterns consistent with our results (Dzwonko and Gawronski, 2002). Recovery from past litter removal is a long-lasting process and consequently the impact is still evident long after abandonment of the practice (Kreutzer, 1972; Hüttl and Schaaf, 1995). With the removal of forest litter, seeds, particularly acorns, were removed in large quantities. Additionally, deciduous trees are more vulnerable to browsing damages than pine. This is confirmed by modelling studies which showed suppressed regeneration of downy oak during periods with intense grazing (Weber et al., 2008a). The practise of non-timber forest uses has presumably delayed the succession from pine to downy oak. After abandonment of litter collecting and wood pasture some 50 y ago, substantial recruitment of downy oak could establish and pine was again subjected to increased competition (Weber et al., 2008b). We assume that in stands previously affected by non-timber forest uses, the shift from pine to downy oak has started with a decade-long time lag and will continue at an accelerated rate in the next decades.

Different processes were relevant for the observed changes in tree species composition at higher altitudes. The shift from spruce to larch corresponds to regional management goals de- clared in the majority of forest management plans. According to these plans the promotion of larch recruitment was a central silvicultural aim as larch was considered the most valuable tree species by foresters. The forest management plan for the commune of Zeneggen for example asks, "Because of its valuable wood it [the larch] should be increasingly favoured over the other species in the future and treated preferentially when thinning" (translated from the Forest Management Plan of Zeneggen, 1929, p. 12). However, quantitative estimation of the effect of management efforts is not possible as figures for timber harvesting and artificial regeneration are not available on the fine spatial scale required here. While the effect is difficult to prove statistically there is striking correspondence between the management aim and the observed changes in tree species composition that can be inferred.

It is a main challenge in historical ecological research to reconstruct quantitative time series for vegetation changes based on comparison between historical and modern vegetation records often with different accuracies and spatial resolutions. There is no standard procedure how to deal with this problem and it is therefore essential to carefully evaluate and remove systematic bias resulting from such comparison (Bürgi et al., 2000; Egan and Howell, 2001). In our study, we apply a conversion key to make this comparison possible (Tab. I). As it is clear that the values used for this conversion key are not based on strictly objective criteria we used moderate splits rather than extreme estimates in order to reduce the range of potential misinterpretations (e.g., 70 and $30 \%$ for two species instead of 90/10 or 55/45). Further, potential inaccuracies due to single misinterpretations are balanced by aggregating the modern tree species occurrence into the boundaries of historical forest compartments (one compartment contains eight polygons in average). The plausibility of our findings in retrospect supports the reliability of our procedure. A systematic and quantitative assessment of anthropogenic effects on regional species composition can only be based on detailed reconstruction of the historic anthropogenic disturbance regime including regime components such as the disturbance type, spatial distribution and intensity. This requires careful examination and combination of different historical source types (Axelsson et al., 2002; Foster et al., 2002). For our case study in the Swiss Rhone valley we relied on a uniquely rich dataset about traditional non-timber forest uses in the region (Gimmi et al., 2008).

Our study highlights the importance of land-use history for the understanding of current ecological processes. The shift from pine to deciduous trees in low elevation forests of the Swiss Rhone valley can probably not be explained by effects of climate change alone. Moreover, changes in the anthropogenic disturbance regime contributed significantly to the pattern of observed changes. Concomitant effects of climate and landuse changes both operate on different scales. Climate change explains the regional trend towards increased pine mortality in the region whereas land-use history affects the spread of deciduous trees on a local scale. Beyond the Valais, several other inner-alpine valleys in the European Alps have been similarly affected by ancient or recent land-use changes. We therefore 
expect that in those regions similar environmental changes are in process.

Acknowledgements: This study was part of the "Scots Pine Project" within the WSL Research Program "Forest Dynamics". We thank Ben Poulter for his language correction. The constructive comments of the editors and two anonymus reviewers helped much to improve the quality of this manuscript.

\section{REFERENCES}

Albert C.H., Thuiller W., Lavorel S., Davies I.D., and Garbolino E., 2008. Land-use change and subalpine tree dynamics: colonization of Larix decidua in French subalpine grasslands. J. Appl. Ecol. 45: 659-669.

Axelsson A-L. and Östlund L., 2001. Retrospective gap analysis in a Swedish boreal forest landscape using historical data. For. Ecol. Manage. 147: 109-122.

Axelsson A-L., Östlund L., and Hellberg E., 2002. Changes in mixed deciduous forests of boreal Sweden 1866-1999 based on interpretation of historical records. Landscape Ecol. 17: 403-418.

Bigler C., Bräker O.U., Bugmann H., Dobbertin M., and Rigling A., 2006. Drought as an inciting mortality factor in Scot pine stands of the Valais, Switzerland. Ecosystems 9: 330-343.

Birks H.J.B., Line J.M., and Persson T., 1988. Quantitative estimation of human impact on cultural landscape development. In: Birks H.H., Birks H.J.B., Kaland P.E., and Moe D. (Eds.), The cultural landscape, past, present and future, Cambridge University Press, Cambridge, pp. 229-240.

Bürgi M., 1999. A case study of forest change in the Swiss lowlands. Landscape Ecol. 14: 567-575.

Bürgi M., Russell E.W.B., and Motzkin G., 2000. Effects of postsettlement human activities on forest composition in the north-eastern United States: a comparative approach. J. Biogeogr. 27: 1123-1138.

Bürgi M. and Gimmi U., 2007. Three objectives of historical ecology: the case of litter collecting in Central European forests. Landscape Ecol. 22: 77-87.

Chauchard S., Carcaillet C., and Guibal F., 2007. Patterns of landuse abandonment control tree-recruitment and forest dynamics in Mediterranean mountains. Ecosystems 10: 936-948.

Curt T., Prévosto B., Klesczewski M., and Lepart J., 2003. Post-grazing Scots pine colonization of mid-elevation heathlands: population structure, impact on vegetation composition and diversity. Ann. For. Sci. 60: 711-724.

Dambrine E., Dupouey J.L., Laut L., Humbert L., Thinon M., Beaufils T., and Richard H., 2007. Present forest biodiversity patterns in France related to former Roman agriculture. Ecology 88: 1430-1439.

De Quervain F., 1963-1967. Geotechnische Karte der Schweiz, Schweizerische Geotechnische Kommission, Bern.

Dobbertin M., Mayer P., Wohlgemuth T., Feldmeyer-Christe E., Graf U., Zimmermann N., and Rigling A., 2005. The decline of Pinus sylvestris L. forests in the Swiss Rhone valley - a result of drought stress? Phyton 44: 153-156.

Dzwonko Z., 2001. Effect of proximity to ancient deciduous woodland on restoration of the field layer vegetation in a pine plantation. Ecography 24: 198-204.

Dzwonko Z. and Gawronski S., 2002. Effect of litter removal on species richness and acidification of a mixed oak-pine woodland. Biol. Conserv. 106: 389-398.

Egan D. and Howell E.A., 2001. The historical ecology handbook. Island Press, Washington DC, $457 \mathrm{p}$.

Flühler H., Keller T., and Schwager H., 1981. Die Immissionsbelastung der Föhrenwälder im Walliser Rhonetal. In: Waldschäden im
Walliser Rhonetal (Schweiz), Mitteilungen der Eidgenössischen Anstalt für das forstliche Versuchswesen 57, pp. 361-499.

Foster D.R., 2002. Insights from historical geography to ecology and conservation: lessons from New England landscape. J. Biogeogr. 29: 1269-1275.

Foster D.R., Hall B., Barry S., Clayden S., and Pershall T., 2002. Cultural, environmental and historical controls of vegetation patterns and the modern conservation setting on the island of Martha's Vineyard, USA. J. Biogeogr. 29: 1381-1400.

Foster D.R., Swanson F., Aver J., Burke I., Borwaw N., Tilman D., and Knapp A., 2003. The importance of land-use legacies to ecology and conservation. BioScience 53: 77-88.

Fuhrer J., Beniston M., Fischlin A., Frei C., Goyette S., Jasper K., and Pfister C., 2006. Climate risks and their impact on agriculture and forests in Switzerland. Clim. Change 79: 79-102.

Garbarino M., Weisberg P.J., and Motta R., 2009. Interacting effects of physical environment and anthropogenic disturbance on the structure of European Larch (Larix decidua Mill.) forests. For. Ecol. Manage. 257: $1794-1802$.

Gimmi U. and Bürgi M., 2007. Using oral history and forest management plans to reconstruct traditional non-timber forest uses in the Swiss Rhone valley (Valais). Environ. Hist. 13: 211-246.

Gimmi U., Bürgi M., and Wohlgemuth T., 2004. Wie oft brannte der Walliser Wald im 20. Jahrhundert? Schweiz. Z. Forstwes. 155: 437440.

Gimmi U., Bürgi M., and Stuber M., 2008. Reconstructing anthropogenic disturbance regimes in forest ecosystems - a case study from the Swiss Rhone valley. Ecosystems 11: 113-124.

Gimmi U., Wolf A., Bürgi M., Scherstjanoi M., and Bugmann H., 2009. Quantifying disturbance effects on vegetation carbon pools in mountain forests based on historical data. Reg. Environ. Change 9: 121130.

Glatzel G., 1990. The nitrogen status of Austrian forest ecosystems as influenced by atmospheric deposition, biomass harvesting and lateral organomass exchange. Plant Soil 128: 67-74.

Glatzel G., 1991. The impact of historic land-use and modern forestry on nutrient relations of Central Europe forest ecosystems. Fert. Res. 27: $1-8$.

Graae B.J., Sunde P.B., and Fritzbøger B., 2003. Vegetation and soil differences in ancient opposed to new forests. For. Ecol. Manage. 177: 179-190.

Hansen A.J., Neilson R.R., Dale V.H., Flather C.H., Iverson L.R., Currie D.J., Shafer S., Cook R., and Bartlein P.J., 2001. Global change in forests: Responses of species, communities, and biomes. BioScience 51: 765-779.

Hüttl R.F. and Schaaf W., 1995. Nutrient supply of forest soils in relation to management and site history. Plant Soil 168: 31-41.

Kirby K.J. and Watkins C., 1998. The ecological history of European forests, CAB International, Cambridge, 392 p.

Kreutzer K., 1972. Über den Einfluss der Streunutzung auf den Stickstoffhaushalt von Kiefernbeständen (Pinus sylvestris L.). Forstwiss. Centbl. 91: 263-9.

Leps J. and Smilauer P., 2003. Multivariate analysis of ecological data using CANOCO. Cambridge University Press, Cambridge, 269 p.

Leuzinger S., Zotz G., Asshoff R., and Korner C., 2005. Responses of deciduos forest trees to severe drought in Central Europe. Tree Physiol. 25: 641-650.

Moser B., Gimmi U., and Wohlgemuth T., 2006. Ausbreitung des Erdbeerspinats Blitum virgatum nach dem Waldbrand von Leuk, Wallis (2003). Bot. Helv. 116: 179-183.

Moser B., Temperli C., Schneiter G., Wohlgemuth T., in review. Drought induced tree species shift after wildfire disturbance in a Central Alpine region? Eur. J. For. Res. 
Motta R. and Garbarino F., 2003. Stand history and its consequences for the present and future dynamic in two silver fir (Abies alba Mill.) stands in the high Pesio Valley (Piedmont, Italy). Ann. For. Sci. 60: $361-370$.

Motta R., Morales M., and Nola P., 2006. Human land-use, forest dynamics and tree growth at the treeline in the Western Italian Alps. Ann. For. Sci. 63: 739-747.

Poyatos R., Llorens P., Piñol J., and Rubio C. 2008. Response of Scots pine (Pinus sylvestris L.) and pubescent oak (Quercus pubescens Willd.) to soil and atmospheric water deficits under Mediterranean mountain climate. Ann. For. Sci. 65: 306.

Prévosto B., Dambirne E., Moares C., and Curt T., 2004. Effects of volcanic ash chemistry and former agricultural use on the soils and vegetation of naturally regenerated woodlands in the Massif Central, France. Catena 56: 239-261.

Rebetez M. and Dobbertin M., 2004. Climate change may already threaten Scots pine stands in the Swiss Alps. Theor. Appl. Climatol. 79: 1-9.

Richardson D.M., Rundel P.W., Jackson S.T., Teskey R.O., Aronson J., Bytnerowicz A., Wingfield M.J., and Proches S., 2007. Human impacts in pine forests: past, present, and future. Annu. Rev. Ecol. Evol. Syst. 38: 275-297.

Rigling A. and Cherubini P., 1999. Wieso sterben die Waldföhren im "Telwald" bei Visp? Eine Zusammenfassung bisheriger Studien und eine dendroökologische Untersuchung. Schweiz. Z. Forstwes. 150: 113-131.

Rigling A., Dobbertin M., and Wohlgemuth T., 2004. Waldföhrenwälder der Alpen im Umbruch - eine Bioindikation für Global Change? Bauhinia 18: 56-57.

Rigling A., Dobbertin M., Bürgi M., Feldmeier-Christe E., Gimmi U., Ginzler C., Graf U., Mayer P., Zweifel R., and Wohlgemuth T., 2006. Baumartenwechsel in den Walliser Waldföhrenwäldern. In: Wohlgemuth T. (Ed.), Wald und Klimawandel, Forum für Wissen 2006, Birmensdorf, pp. 23-33.
Schönfeld U., Rigling D., and Polomski J., 2004. Eine neue Gefahr für die Föhren der Schweiz? Der Kiefernholznematode. Wald Holz 85: $35-37$.

Spiecker H., 1999. Overview of recent growth trends in European forests. Water Air Soil Pollut. 116: 33-46.

Weber P., Rigling A., and Bugmann H., 2007. Radial growth responses to drought of Pinus sylvestris and Quercus pubescens in an inner-Alpine dry valley. J. Veg. Sci. 18: 777-792.

Weber P., Bugmann H., and Rigling A., 2008a. Sensitivity of stand dynamics to grazing in mixed Pinus sylvestris and Quercus pubescens forests: a modelling study. Ecol. Model. 210: 301-311.

Weber P., Bugmann H., Fonti P., and Rigling A., 2008b. Using retrospective dynamic competition indices to estimate future forest succession. For. Ecol. Manage. 294: 96-106.

Werlen C., 1994. Elaboration de la carte de végétation forestière du Valais. Schweiz. Z. Forstwes. 14: 607-617.

Wermelinger B., Rigling A., Schneider Mathis D., and Dobbertin M., 2008. Assessing the role of bark- and wood-boring insects in the decline of Scots pine (Pinus sylvestris) in the Swiss Rhone valley. Ecol. Entomol. 33: 239-249.

Wohlgemuth T., Bürgi M., Scheidegger C., and Schütz M., 2002. Dominance reduction of species through disturbance - a proposed management principle for Central European forests. For. Ecol. Manage. 166: 1-15.

Wulf M., 2004. Plant species richness of afforestations with different former use and habitat continuity. For. Ecol. Manage. 195: 191-204.

Zumbrunnen T., Bugmann H., Conedera M., and Bürgi M., 2009. Linking forest fire regimes and climate - a historical analysis in a dry inner Alpine valley. Ecosystems 12: 73-86.

Zweifel R., Rigling A., and Dobbertin M., 2009. Species-specific stomatal response of trees to microclimate - a functional link between climate change and vegetation dynamics. J. Veg. Sci. 20: 442-454. 